\title{
The bird species diversity in the wintering season is negatively associated with precipitation, tree species diversity and stand density in the Sierra Madre Occidental, Durango, Mexico
}

\author{
C. Wehenkel1,4, A. Reyes-Martínez¹, J. H. Martínez-Guerrero², C. Pinedo-Alvarez ${ }^{3}$ \\ and C. A. López-Sánchez ${ }^{1}$
}

\author{
${ }^{I}$ Instituto de Silvicultura e Industria de la Madera, Universidad Juárez del Estado de Durango, Boulevard del \\ Guadiana 501, Fraccionamiento Ciudad Universitaria, 34160 Durango, Dgo., México \\ ${ }^{2}$ Facultad de Medicina Veterinaria y Zootecnia. Universidad Juárez del Estado de Durango, Carretera al Mezquital \\ Km 11. Durango, Dgo., Mexico \\ ${ }^{3}$ Departamento de Recursos Naturales, Facultad de Zootecnia y Ecología, Universidad Autonoma de Chihuahua \\ (UACH), Perif. Fco. R. Almada Km 1, 31453 Chihuahua, Chih., Mexico \\ ${ }^{4}$ Corresponding author: wehenkel@ujed.mx
}

Keywords: Breeding bird, Migratory bird, Local migratory birds, Sedentary birds.

\begin{abstract}
Bird migration constitutes a redistribution of bird diversity that radically changes the composition of the bird community worldwide. It comprises about $19 \%$ of the world's bird species. Several studies have indicated that changes in avian community structure and differences in bird richness in different seasons are mainly driven by seasonality and by winter harshness, and that the associated costs increase with the distance involved. Western Mexico is an important wintering area for most passerines that breed in western North America, and that travel long on the long-distance Central and Pacific migration routes. In this study, we examined bird species richness and diversity during the breeding and wintering seasons in the Central Sierra Madre Occidental (SMO), North Durango (Mexico) in relation to i) tree species diversity, ii) tree dimension, iii) forest stand density and site quality, iv) density and dimension of snag trees, and v) various climate variables. The overall aim of the study was to determine how the observed associations between bird species diversity and variables i-v are affected by the season considered (breeding or wintering). The diversity of bird species in the breeding season was not affected by any of the climate and forest stand variables considered. In contrast, bird species diversity in the wintering season was significantly and weakly to moderately associated with climate variables, tree species diversity and stand density, although not with density or dimension of snag trees. Bird species diversity was higher at lower elevations and in drier and warmer locations of the SMO. The association detected is therefore mainly a local migratory phenomenon.
\end{abstract}

Abbreviation: AAI-Annual Aridity Index; MAP-Mean Annual Precipitation; SMO-Sierra Madre Occidental

\section{Introduction}

Studies of continental flora and fauna have repeatedly confirmed that total species richness is strongly associated with temperature, precipitation and net primary productivity (Currie et al. 2004). This relationship particularly applies to bird species richness. Rahbek et al. (2007) studied bird diversity in 78 elevational gradients in mountains in both hemispheres (at latitudes spanning $24.5^{\circ} \mathrm{S}$ to $48.2^{\circ} \mathrm{N}$ ) and including gradients from various climates, biogeographical regions and habitat types. These authors found that bird elevational diversity was strongly associated with current climate as the main driver of diversity, particularly in combination with variations in temperature and water availability. They also found that bird diversity in humid mountain ecosystems either decreased or reached a low-elevation plateau, whereas on dry mountains it was unimodal or reached a broad, low-elevation plateau, usually with a mid-elevation maximum. However, the species-area and mid-domain effects were not important as primary factors of bird elevational diversity.

Rahbek and Graves (2001) conducted an extensive study in South America of the patterns of bird richness, using a database of the geographic ranges of 2,869 bird species and 16 climatic variables. These authors found that topographic heterogeneity, the topographic heterogeneity $\times$ latitude interaction, precipitation, ecosystem diversity and cloud cover were the most important factors that positively determined bird species richness in regression models. At the finer scales of resolution, precipitation was the best predictor and was positively associated with bird species richness.

Vegetation type strongly influences bird community structure (Terborgh et al. 1990) and diversity (Balda 1969). Thus, the avian diversity positively related to size of the area (Ambuel and Temple 1983), age of forest stands (Bergner et al. 2015), habitat heterogeneity, density and dimension of snag trees (Gibbs et al. 1993) and of mature trees (DeWalt 
et al. 2003), and forest density, composition and structure (Zellweger et al. 2016). However, Ralph (1985) reported an inverse relationship between avian species diversity and an index of foliage height diversity for Nothofagus beech forests in Patagonia. In a study carried out in India, Daniels et al. (1992) found that bird species richness was negatively correlated with the diversity of woody plant species and with vertical stratification, canopy density and tree density in natural forests.

Several studies have indicated that variations in avian community structure and differences in bird richness (Massey and Palacios 1994), social (Dolby and Grubb 2000) and foraging behavior in different seasons are mainly due to migratory patterns (Amador et al. 2006), food availability (Mellink et al. 1996), minimization of predation risk (Roth et al. 2006) and optimization of energy regulation (Brown and Sherry 2008).

Bird migration constitutes a redistribution of bird diversity that radically changes the composition of the bird community worldwide (Somveille et al. 2013). It involves about $19 \%$ of the world's 9,856 extant bird species (Kirby et al. 2008). Migration is mainly driven by seasonality and by winter harshness, and its costs increase with the distance involved (Somveille et al. 2015). Current climatic trends result in mismatches in several factors (e.g., food supplies, snow cover) that may affect the success of avian migration as the birds may not be able to adjust to the new conditions (Carey 2009). The needs of migratory birds must be fulfilled during the breeding season and during spring and autumn migration and wintering. However, most research and management activities have focused on the breeding season. Information about geographic distributions, wintering sites, habitat use and basic ecology is lacking. This particularly applies to the wintering season, when birds require sites that provide shelter and food resources needed for survival and that enable them to develop nutrient reserves for spring migration and possibly reproduction (Faaborg et al. 2010). Individuals of several migratory bird species are able to actively select wintering areas in relation to specific climatic conditions (Perez-Moreno et al. 2016).

Western Mexico is an important wintering area for most passerines that breed in western North America (Hutto 1989) and that travel on the long-distance Central and Pacific avian migration routes (Berlanga et al. 2010). The coastal lowlands of the Sierra Madre Occidental are wintering grounds for long-distance bird migrants and also for short-distance or local migrants (Nocedal 1994).

In this study, we examined bird species richness and diversity during the breeding and wintering seasons in the Central Sierra Madre Occidental, North Durango (Mexico) in relation to i) tree species diversity, ii) tree dimension, iii) forest stand density and site quality, iv) density and dimension of snag trees, and v) various climate variables. The overall aim of the study was to determine how the observed associations between bird species diversity and variables i) to v) are affected by the season considered (breeding or wintering). All these variables could significantly explain the variance in avian species diversity (Balda 1969, Gibbs et al. 1993, Rahbek and Graves 2001, DeWalt et al. 2003, Rahbek et al. 2007, Somveille et al. 2013, 2015, Zellweger et al. 2016).

\section{Material and methods}

\section{Study area}

This study was conducted in the municipalities of Guanacevi, Ocampo and San Bernardo (forest region UMAFOR 1001), in the Central Sierra Madre Occidental, Durango (Mexico) (Fig. 1). In order to determine bird species richness and diversity and tree species diversity and density, 41 locations in a network of area $2.5 \mathrm{~km} \times 2.5 \mathrm{~km}$ were con-
Figure 1. Location of study area in three municipalities (Guanacevi, Ocampo and San Bernardo) and forest region 1001 in the northern state of Durango, Mexico. Source: Microsoft; Nokia (19 May 2017). "Durango, Mexico" (Map). Bing Maps. Microsoft. Retrieved 19 May 2017.

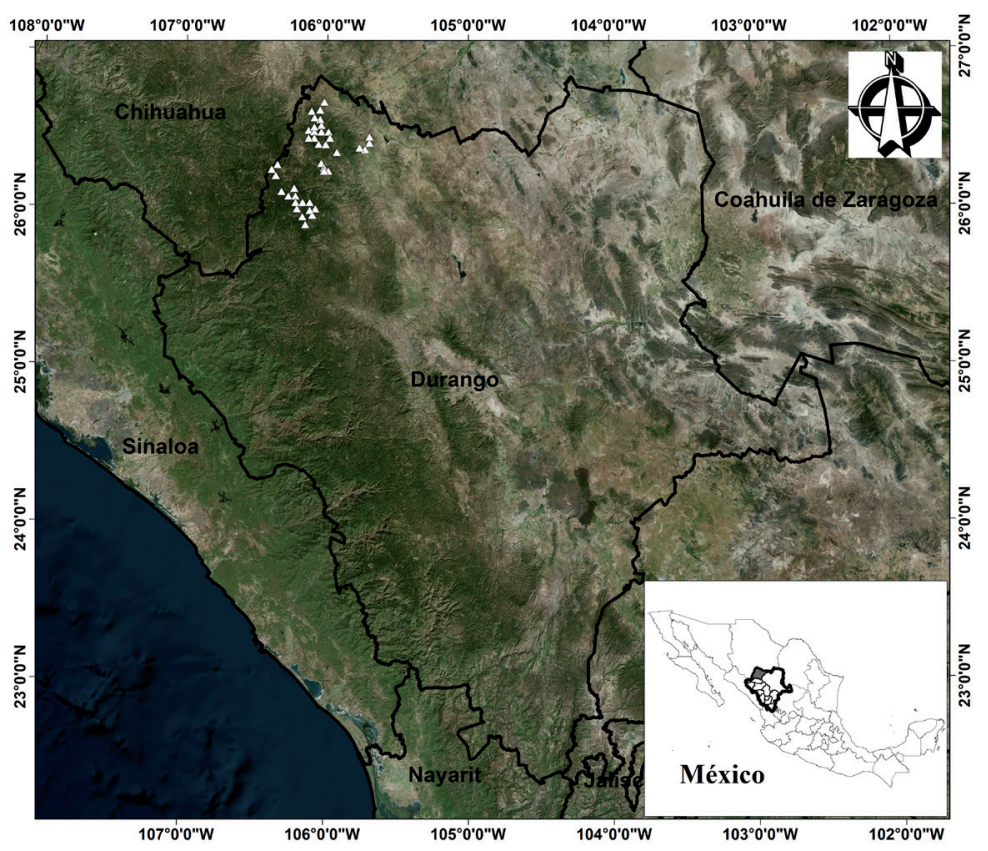


sidered (Fig. 1). The elevation in the study area ranges between 1,758 and 2,963 $\mathrm{m}$ (average 2,618 m) above sea level. The climate ranges from temperate to subtropical, with annual rainfall between 550 and $794 \mathrm{~mm}$ and an annual average of $664 \mathrm{~mm}$. The mean annual temperature varies from 8.7 to $16.1^{\circ} \mathrm{C}$, with an annual average of $11.1^{\circ} \mathrm{C}$ (mean temperature ranges from 3.4 to $9.1^{\circ} \mathrm{C}$ in the coldest month and from 13.0 to $22.3^{\circ} \mathrm{C}$ in the warmest month) (Rehfeldt 2006). The predominant types of vegetation are pine-oak forests, sometimes mixed with Abies durangensis Martínez, Cupressus spp, Pseudotsuga menziesii Brisseau de Mirbel, Picea chihuahuana Martínez, Arbutus spp., Juniperus spp. and other tree species (Silva-Flores et al. 2014). A total of 1,747 trees were recorded. Fourteen tree species were found in the 41 locations: Arbustus spp. (3.0\% of all trees), Juniperus deppeana Steud. (4.7\%), Pinus arizonica Engelm. (46.0\%), P. cembroides Zucc. (9.2\%), P. chihuahuana Martínez (0.1\%), P. durangensis Martínez (4.4\%), P. engelmannii Carr. (0.1\%), P. leiophylla Schl. \& Cham. (5.2\%), P. strobiformis Engelm. (5.3\%), Populus tremuloides Michx. (0.6\%), Pseudotsuga menziesii (Mirb.) Franco (1.9\%), Quercus fulva Liebm. (0.1\%), Q. crassifolia Humb \& Bonpl. (7.2\%) and Q. sideroxyla Hump. \& Bonpl. (12.2\%). Pinus arizonica predominated in $66 \%$ of all locations, while Pinus chihuahuana, Pinus engelmannii, Pseudotsuga menziesii and Quercus fulva occurred in only one location.

\section{Datasets}

Bird monitoring. Bird monitoring was conducted between May 2 and 16 in 2015 and between January 3 and 16 in 2016, i.e., in the breeding and wintering seasons in the study area (Fig. 1). Each location was monitored between 7:00 and 12:00 h by using the previously described point count method (Bibby et al. 2000). Briefly, the birds were quantified by visual observation and by their calls, in each sampling circle of radius of $25 \mathrm{~m}$. Monitoring was conducted for 15 minutes at each point; the researcher began counting birds on entering within a radius of 200 meters of the centre of the sampling circle. The absolute frequencies of birds were recorded (for details see Martínez-Guerrero et al. 2011). Table A1 in the Appendix lists the birds species spotted in different seasons.

Calculation of the diversity of bird and tree species. Bird and tree species diversities (Table A2 in the Appendix) were calculated by the so-called Hill numbers or diversity profile $v_{a}$ (Gregorius 1978), where $a$ is a real number ranging from zero to infinity. The following are the most illustrative values of the subscript $a$ in such diversity profiles: (i) $a=0$, where the diversity corresponds to the total number of species; (ii) $a=2$ as the effective species number, and (iii) $a=\infty$, where only the relative frequency of the most frequent species determines the diversity. In the present study, the diversity profiles were represented by all three diversities for each location. Thus, each location was characterized by the total number (richness), the effective number, inherent in Simpson diversity $\left(D=1-\sum \mathrm{p}_{\mathrm{i}}^{2}\right)$, and the number of prevalent variants (Gregorius 1978). All variants have the same abundance when $v_{0}, v_{2}$ and $v_{\infty}$ have the

$$
v_{a}=v_{a}(p)=\left(\sum_{i} P_{i}^{a}\right)^{\frac{1}{1-a}}
$$

same value (see details in Silva-Flores et al. 2014). If $p_{i}$ is the relative frequency of a tree species $i$, then we have:

Forest stand variables. The following variables were measured at three points every $50 \mathrm{~m}$ along the transect, beginning from the bird monitoring counting point and covering an area of about 1.5 ha: total number of trees, genera and species, the basal area of each tree species and the total basal area per hectare $\left(G_{\text {total }}, \mathrm{m}^{2}\right)$, height of the $10 \%$ of the biggest trees per ha $\left(H_{10 \%}, \mathrm{~m}\right)$, the diameter at breast height of the $10 \%$ of the biggest trees per ha $\left(D B H_{10 \%}, \mathrm{~cm}\right)$, the basal area of dead trees per hectare $\left(G_{\text {dead }}, \mathrm{m}^{2}\right)$, the height of dead trees within the $10 \%$ of the biggest trees per ha $\left(H_{10 \% \text {,dead }}, \mathrm{m}\right)$, the diameter at breast height of dead trees within the $10 \%$ of the biggest trees per ha $\left(D B H_{10 \% \text {,dead }}, \mathrm{cm}\right)$, the basal area of tree with dieback per hectare $\left(G_{d i e}, \mathrm{~m}^{2}\right)$, the height of drying trees within the $10 \%$ the biggest trees per ha $\left(H_{10 \%, d i e}, \mathrm{~m}\right)$ and the diameter at breast height of drying trees within the $10 \%$ of the biggest trees per ha $\left(\mathrm{DBH}_{10 \% \text {,die }}, \mathrm{cm}\right)$ (Table 2). Dying trees were trees in which dieback of more than $50 \%$ of the treetop had occurred.

The tree dimensions were represented by tree diameter and height. Tree height is also an indicator of site quality ( $\mathrm{McNab}$ 1989), and basal area indicates forest density (Reineke 1933). The basal areas were measured using angle-count sampling (Bitterlich 1952). Tree heights were measured with a Haglof Vertex III hypsometer (Haglof, Langsele, Sweden), and the diameters were measured with a diameter tape.

Climate variables. Species richness is strongly associated with climate (Currie et al. 2004). Therefore, the climate model of Rehfeldt (2006), which was created on the thin plate splines of Hutchinson (Hutchinson 2004), was used to determine climate variables in each plot. The model produced climate surfaces from monthly normalized values of total precipitation and mean, maximum and minimum temperatures collected between 1961 and 1990 from approximately 6,000 weather stations (183 stations in Durango State). Twenty-two variables were derived from the original data, which also included an annual aridity index (AAI), defined as the ratio of square root of degree days $>5^{\circ} \mathrm{C}$ (DD5) to mean annual precipitation (MAP). Higher values of the AAI denote more arid climate. The AAI index is a powerful climatic variable for describing and predicting the species distribution (for further details, see Silva-Flores et al. 2014). Descriptive statistics of these and other climate variables are shown in Table A2.

\section{Data analysis}

Descriptive statistics were calculated and Principal Component Analysis (PCA) (significance level $\alpha=0.001$ ) and Spearman's Correlation Analysis $(\alpha=0.01)$ were performed using XLSTAT version 2015.6.01.25740 (XLSTAT 2016). PCA with varimax rotation (Wolfgang and Leopold 2012) was used to convert possibly correlated variables into a set of values of linearly uncorrelated variables (named factors 
(components)) and to select independent variables (Table 1) for multiple (linear) regressions. Bartlett's test of sphericity was used to evaluate the hypothesis that the correlations in the matrix are zero.

The Kruskal - Wallis post-hoc test (Tukey and Kramer approach) (Kruskal and Wallis 1952) was used to test whether the observed differences in bird species diversity between the breeding and wintering season occur as random events, rather than by directed forces. The test was implemented using the "PMCMR" package (Pohlert 2014) included within the R 3.2.2 statistical package (R Development Core Team 2015) and considering a significance level $\alpha=0.01$.

The non-parametric two-sided one-dimensional Kolmogorov-Smirnov test was used to define the largest absolute difference $(D)$ between the two cumulative distribution functions - bird species diversity in the breeding and wintering seasons - as a measure of disagreement and to test whether $D$ occurred as a random event. The probability of incorrectness $(P)$ was thus also produced (Lopes et al. 2007). This test was implemented using the "stats" package of $\mathrm{R}$ and considering a significance level of $\alpha=0.01$.

Finally, multiple (linear) regression analyses were carried out. Only independent variables that were not highly correlated with other independent variables (i.e., only one variable from each PCA factor) and most associated with the bird species diversity were included to ensure valid results for any individual predictor.

Model variables were excluded if the probability of incorrectness $(P)$ was greater than or equal to $5 \%$. Stepwise selection (forward and backward) was performed to select the most informative variables for inclusion in the model. This procedure was carried out using the step AIC() function and the exact Akaike information criterion (AIC) and was implemented using the "MASS" package (Venables and Ripley 2002). The adjusted coefficient of determination $\left(R_{A d j}^{2}\right)$ and residual standard error (RSE) were used as goodness-of-fit indices.

\section{Results}

A total of 1,447 birds were recorded during the study: 415 in the breeding season and 1,032 in the wintering season. These included 79 bird species, 59 of which were detected in the breeding and 54 in the wintering season. Of these, 25 species were only found in the breeding season, 20 species only in the wintering season and 34 in both seasons. In both seasons, resident birds were the most frequent in almost all locations. The yellow-eyed Junco (Junco phaeonotus) was the predominant bird species in $17 \%$ of the locations at elevations of $2,683 \mathrm{~m} \pm 261 \mathrm{~m}$ in the breeding season and $32 \%$ of the locations at elevations of 2,676 $\mathrm{m} \pm 269 \mathrm{~m}$ in the wintering season. The Ruby-crowned Kinglet (Regulus calendula) and the Dark-eyed Junco (Junco hyemalis) (migrated from USA and Canada) were the most common birds in five locations at elevations of between 2,492 and 2,879 $\mathrm{m}$ in the wintering season (Table A2).

The Kruskal-Wallis test showed no significant differences in mean bird species diversity indices $v_{0}, v_{2}$ or $v_{\infty}$ between the breeding and wintering season $(P=0.07,0.62$ and 0.25$)$. Although the Kolmogorov-Smirnov test did not detect differences in the distributions of the bird species $(D=0.17, P=$ $0.59 ; D=0.26, P=0.20 ; D=0.10, P=0.99)$, the Spearman correlations between the bird species diversity indices in breeding and wintering time were weak and statistically insignificant.

Although bird species diversity in the breeding season was not significantly associated with other variables, the bird species diversity in the wintering season was significantly correlated with almost all climate variables $(P<0.001)$ and site quality (mean height of the $10 \%$ of the biggest trees $\left.\left(H_{10 \%}\right)\right)(P<0.01)$, forest density (basal area $\left.\left(G_{\text {total }}\right)\right)(P<$ $0.01)$ and forest tree diversity (number of prevalent tree species per hectare $\left.\left(v_{\infty, T}\right)\right)(P<0.01)$. However, the avian species diversity was not significantly related to forest density or dimension-density of snag trees.
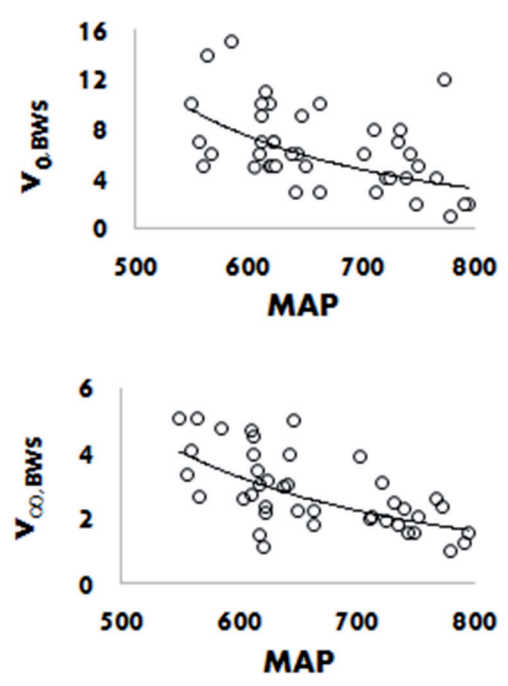

Figure 2. Relationships between number of prevalent tree species $\left(v_{\infty, T}\right)$, total number of bird species in the winter season $\left(v_{0, B W S}\right)$, effective diversity of bird species in the winter season $\left(v_{2, B W S}\right)$, number of prevalent bird species in the winter season $\left(v_{\infty, B W S}\right)$ and mean annual precipitation (MAP) in the study area. 
Table 1. Eigenvalues of each factor group, variability explained by factor groups F1, F2, F3 and F4 and the 29 most important variables within the four factor groups. The variable impact in the factor group increases with the correlation between variable and factor group.

\begin{tabular}{|c|c|c|c|c|c|}
\hline & Factor Group & F1 & F2 & F3 & F4 \\
\hline \multicolumn{2}{|l|}{ Eigenvalue } & 19.58 & 2.91 & 2.23 & 1.85 \\
\hline \multicolumn{2}{|c|}{ Variance explained (\%) } & $67.51 \%$ & $10.05 \%$ & $7.68 \%$ & $6.37 \%$ \\
\hline \multicolumn{2}{|c|}{ Relevant variable } & \multicolumn{4}{|c|}{ variable - factor group correlation } \\
\hline \multicolumn{6}{|c|}{ Tree species diversity } \\
\hline$v_{0, T}$ & Total number of tree species & & & & 0.62 \\
\hline$v_{2, T}$ & Effective number of tree species & & & & 0.76 \\
\hline$v_{\infty, T}$ & Number of prevalent tree species & & & & 0.74 \\
\hline \multicolumn{6}{|c|}{ Forest stand variables } \\
\hline $\mathrm{DBH}_{10 \%}$ & Diameter at breast height of the $10 \%$ of the biggest trees per ha $[\mathrm{cm}]$ & & 0.66 & & \\
\hline $\mathrm{H}_{10 \%}$ & Height of the $10 \%$ of the biggest trees per ha $[\mathrm{m}]$ & -0.68 & & & \\
\hline $\mathrm{G}_{\text {total }}$ & Tree basal area $\left[\mathrm{m}^{2} \mathrm{ha}^{-1}\right]$ & & & 0.75 & \\
\hline $\mathrm{H}_{10 \%, \text { dead }}$ & Height of dead trees within the $10 \%$ of the biggest trees per ha $[\mathrm{m}]$ & & 0.69 & & \\
\hline $\mathrm{G}_{\text {dead }}$ & Tree basal area of dead trees $\left[\mathrm{m}^{2} \mathrm{ha}^{-1}\right]$ & -0.58 & & & \\
\hline $\mathrm{DBH}_{10 \%, d i e}$ & $\begin{array}{l}\text { Diameter at breast height of dying trees within the } 10 \% \text { of the bigger trees } \\
\text { per ha }[\mathrm{cm}]\end{array}$ & & 0.67 & & \\
\hline $\mathrm{H}_{10 \%, d i e}$ & Height of dying trees within the $10 \%$ of the bigger trees per ha $[\mathrm{m}]$ & -0.68 & & & \\
\hline $\mathrm{G}_{\text {die }}$ & Tree basal area of trees with dieback $\left[\mathrm{m}^{2} \mathrm{ha}^{-1}\right]$ & & & 0.64 & \\
\hline \multicolumn{6}{|c|}{ Climate variables } \\
\hline MAT & Mean annual temperature $\left[{ }^{\circ} \mathrm{C}\right]$ & 0.98 & & & \\
\hline MAP & Mean annual precipitation $[\mathrm{mm}]$ & -0.97 & & & \\
\hline GSP & Growing season precipitation, April to September $[\mathrm{mm}]$ & -0.94 & & & \\
\hline MTCM & Mean temperature in the coldest month $\left[{ }^{\circ} \mathrm{C}\right]$ & 0.96 & & & \\
\hline MMIN & Mean minimum temperature in the coldest month $\left[{ }^{\circ} \mathrm{C}\right]$ & 0.97 & & & \\
\hline MTWM & Mean temperature in the warmest month $\left[{ }^{\circ} \mathrm{C}\right]$ & 0.98 & & & \\
\hline MMAX & Mean maximum temperature in the warmest month $\left[{ }^{\circ} \mathrm{C}\right]$ & 0.98 & & & \\
\hline SDAY & Julian date of the last freezing date of spring [Day] & -0.97 & & & \\
\hline FDAY & Julian date of the first freezing date of autumn [Day] & 0.97 & & & \\
\hline FFP & Length of the frost-free period [Day] & 0.97 & & & \\
\hline DD5 & Degree-days $>5$ degrees ${ }^{\circ} \mathrm{C}$ (based on mean monthly temperature) $\left[{ }^{\circ} \mathrm{C}\right]$ & 0.98 & & & \\
\hline GSDD5 & Degree-days $>5$ degrees ${ }^{\circ} \mathrm{C}$ accumulating within the frost-free period $\left[{ }^{\circ} \mathrm{C}\right]$ & 0.98 & & & \\
\hline DD0 & Degree-days $<0$ degrees ${ }^{\circ} \mathrm{C}$ (based on mean monthly temperature) $\left[{ }^{\circ} \mathrm{C}\right]$ & -0.97 & & & \\
\hline SMRPB & Summer precipitation balance: $(\mathrm{Jul}+\mathrm{Aug}+\mathrm{Sep}) /(\mathrm{Apr}+\mathrm{May}+\mathrm{Jun})[\mathrm{mm}]$ & 0.83 & & & \\
\hline SPRP & Spring precipitation (Apr+May) $[\mathrm{mm}]$ & -0.88 & & & \\
\hline SMRP & Summer precipitation $(\mathrm{Jul}+\mathrm{Aug})[\mathrm{mm}]$ & -0.91 & & & \\
\hline WINP & Winter precipitation $(\mathrm{Nov}+\mathrm{Dec}+\mathrm{Jan}+\mathrm{Feb})[\mathrm{mm}]$ & -0.99 & & & \\
\hline AAI & Annual aridity index $\left[\mathrm{dd} 55^{0.5} / \mathrm{mm}\right]$ & 0.99 & & & \\
\hline
\end{tabular}

The effective number of bird species $\left(v_{2, B W S}\right)$ and the numbers of prevalent bird species $\left(v_{\infty, B W S}\right)$ in the wintering season were negatively correlated with the mean annual precipitation (MAP) at $\alpha=0.0001$, but also negatively associated with growing season (GSP), summer (SMRP), winter precipitation (WINP) and frost duration $\left(\mathrm{S}_{\text {day }}\right)$ at $\alpha=0.001$ and with $H_{10 \%}$ and $G_{\text {total }}$. However, $v_{2, B W S}$ and $v_{\infty, B W S}$ were positively and significantly associated with temperature variables and the annual aridity index (AAI) $(\alpha=0.001)$. The total number of bird species in the wintering season $\left(v_{0, B W S}\right)$ was significantly negatively associated with $v_{\infty, T}$ at $\alpha=0.01$ (Tables A2, 2, Fig. 2).

After varimax rotation, the first four PCA axes explained $91.61 \%$ of the total variance (eigenvalues: $\lambda_{1}=19.58, \lambda_{2}=$
2.91, $\lambda_{3}=2.23, \lambda_{4}=1.85$, Table 1). The Bartlett's test revealed that the eigenvalues of the first four principal components were statistically significantly different from each other $(P<0.0001)$. Principal component 1 explains about $67.51 \%$ of the variance and mainly comprises the climate variables and forest stand variables $\left(\mathrm{H}_{10 \%}, \mathrm{G}_{\text {dead }}\right.$ and $\left.\mathrm{H}_{10 \%, \text { die }}\right)$. All climate variables are strongly correlated with each other. Principal component 2 explains $10.05 \%$ of the variance and mainly comprises forest stand variables $\left(\mathrm{DBH}_{10 \%}, \mathrm{H}_{10 \%}\right.$, dead and $\mathrm{DBH}_{10 \% \text {, die }}$. Principal component 3 explains about $7.68 \%$ of the variance and is described by forest stand variables $\left(\mathrm{G}_{\text {total }}\right.$ and $\left.\mathrm{G}_{d i e}\right)$. Finally, principal component 4 explains about $6.37 \%$ of the variance and specifically comprises the Tree species diversity $\left(v_{0, T}, v_{2, T}\right.$ and $\left.v_{\infty, T}\right)$ (Table 1; Fig. 3). 
Table 2. Spearman correlation matrix of attributes of 41 sampling locations in the study area: height of the $10 \%$ biggest trees per ha $\left(\mathrm{H}_{10 \%}\right)$, tree basal area $\left(\mathrm{G}_{\text {total }}\right)$, number of prevalent tree species $\left(v_{\infty, T}\right)$, mean annual precipitation (MAP), degree-days $<0$ degrees ${ }^{\circ} \mathrm{C}$ (based on mean monthly temperature) (DD0), winter precipitation (Nov+Dec+Jan+Feb) (WINP), total number of bird species in the winter season $\left(v_{0, B W S}\right)$, effective number of bird species in the winter season $\left(v_{2, B W S}\right)$ and number of prevalent bird species in the winter season $\left(v_{\infty, B W S}\right)$.

\begin{tabular}{|c|c|c|c|c|c|c|c|c|c|}
\hline Variable & $\mathrm{H}_{10 \%}$ & $\mathrm{G}_{\text {total }}$ & $v_{\infty, T}$ & MAP & DD0 & WINP & $v_{0, B W S}$ & $v_{2, B W S}$ & $v_{\infty, B W s}$ \\
\hline$v_{\infty, T}$ & $0.40 * *$ & $0.17 \mathrm{~ns}$ & & & & & & & \\
\hline MAP & $0.61 * * *$ & $0.46^{* *}$ & $0.51 * * *$ & & & & & & \\
\hline DD0 & $0.54 * * *$ & $0.33^{*}$ & $0.57 * * *$ & & & & & & \\
\hline WINP & $0.61 * * *$ & $0.42 * *$ & $0.50^{* * *}$ & & & & & & \\
\hline$v_{0, B W S}$ & $-0.38^{*}$ & $-0.15 n s$ & $-0.41 * *$ & $-0.50 * * *$ & $-0.47 * *$ & $-0.47 * *$ & & & \\
\hline$v_{2, B W S}$ & $-0.41^{* *}$ & $-0.39^{*}$ & $-0.34 *$ & $-0.63 * * *$ & $-0.54 * * *$ & $-0.57 * * *$ & $0.70^{* *}$ & & \\
\hline$v_{\infty, B W S}$ & $-0.39 *$ & $-0.43^{* *}$ & $-0.28 \mathrm{~ns}$ & $-0.65 * * *$ & $-0.53 * * *$ & $-0.58 * * *$ & $0.55^{* * *}$ & $0.96^{\text {*** }}$ & \\
\hline
\end{tabular}

Note: Asterisks indicate significance: $*=$ at $\mathrm{p}<0.05,{ }^{* *}$ at $\mathrm{p}<0.01$ and $* * *$ at $\mathrm{p}<0.001 ;$ ns $=$ not significant.

Table 3. Regression models for bird-related variables in the winter season 2015-2016: total number of bird species in the winter season $\left(v_{0, B W S}\right)$, effective diversity of bird species in the winter season $\left(v_{2, B W S}\right)$, number of prevalent bird species in the winter season $\left(v_{\infty, B W S}\right)$ against the variable mean annual precipitation (MAP) from $550-794 \mathrm{~mm} . A d j-R^{2}=$ Adjusted $R$-squared, $R S E=$ Residual standard error, $P$-value $=$ probability of incorrectness

\begin{tabular}{lccc}
\hline \multicolumn{1}{c}{ Model } & Adj-R & $R S E$ & $P$-value \\
\hline$v_{0, \mathrm{BWS}}=-0.0214 \mathrm{MAP}+20.7192$ & 0.213 & 2.861 & 0.00140 \\
$v_{2, \mathrm{BWS}}=-0.0615 \mathrm{MAP}+15.0523$ & 0.354 & 1.585 & 0.00002 \\
$v_{\infty, \mathrm{BWS}}=-0.0099 \mathrm{MAP}+9.4233$ & 0.380 & 0.903 & 0.00001 \\
\hline
\end{tabular}

Variables (axes F1 and FZ: $77.56 \%$ )

Figure 3. Independent variables correlated with PCA factors F1 and F2. For abbreviations, see Table A2.

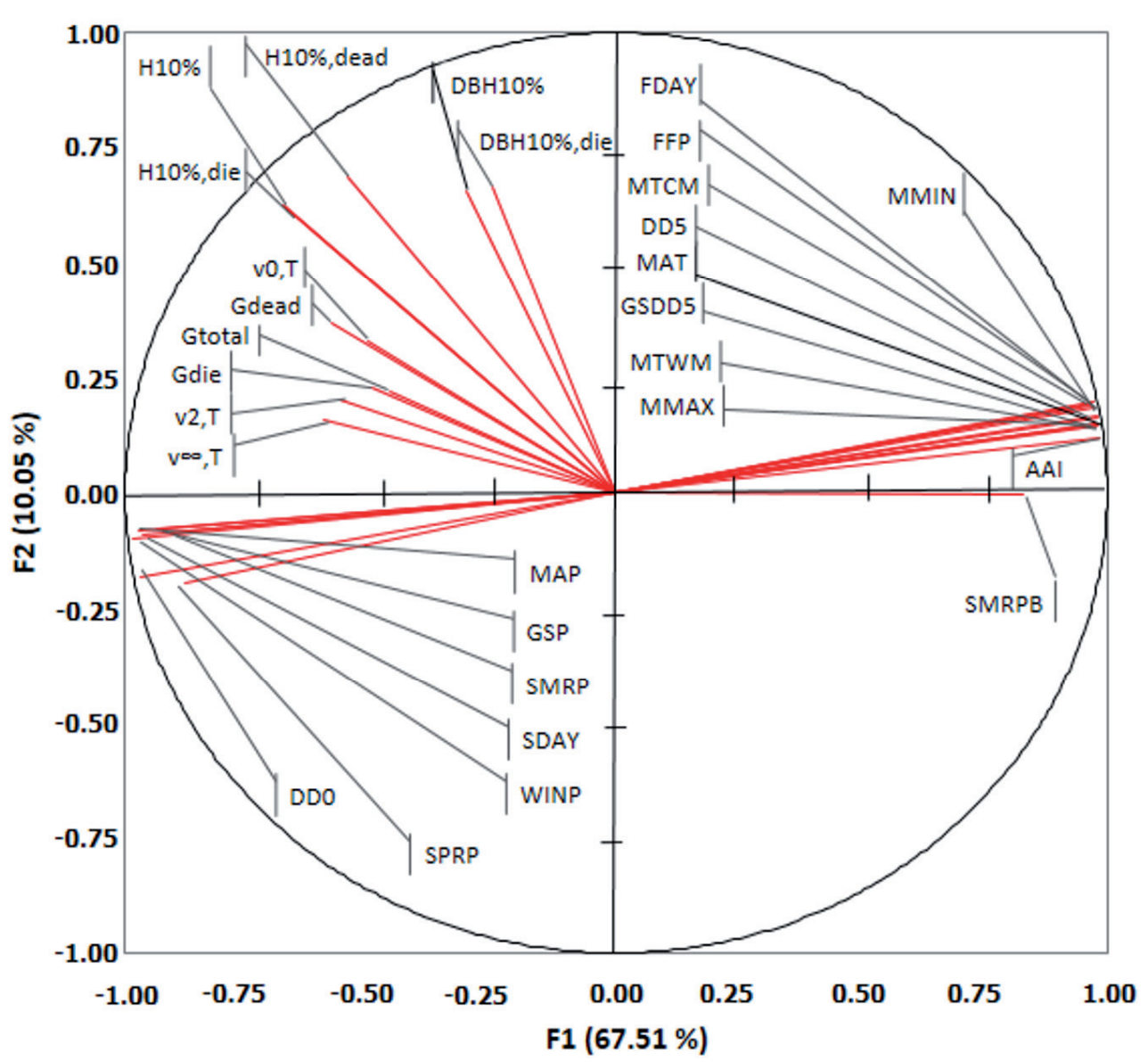




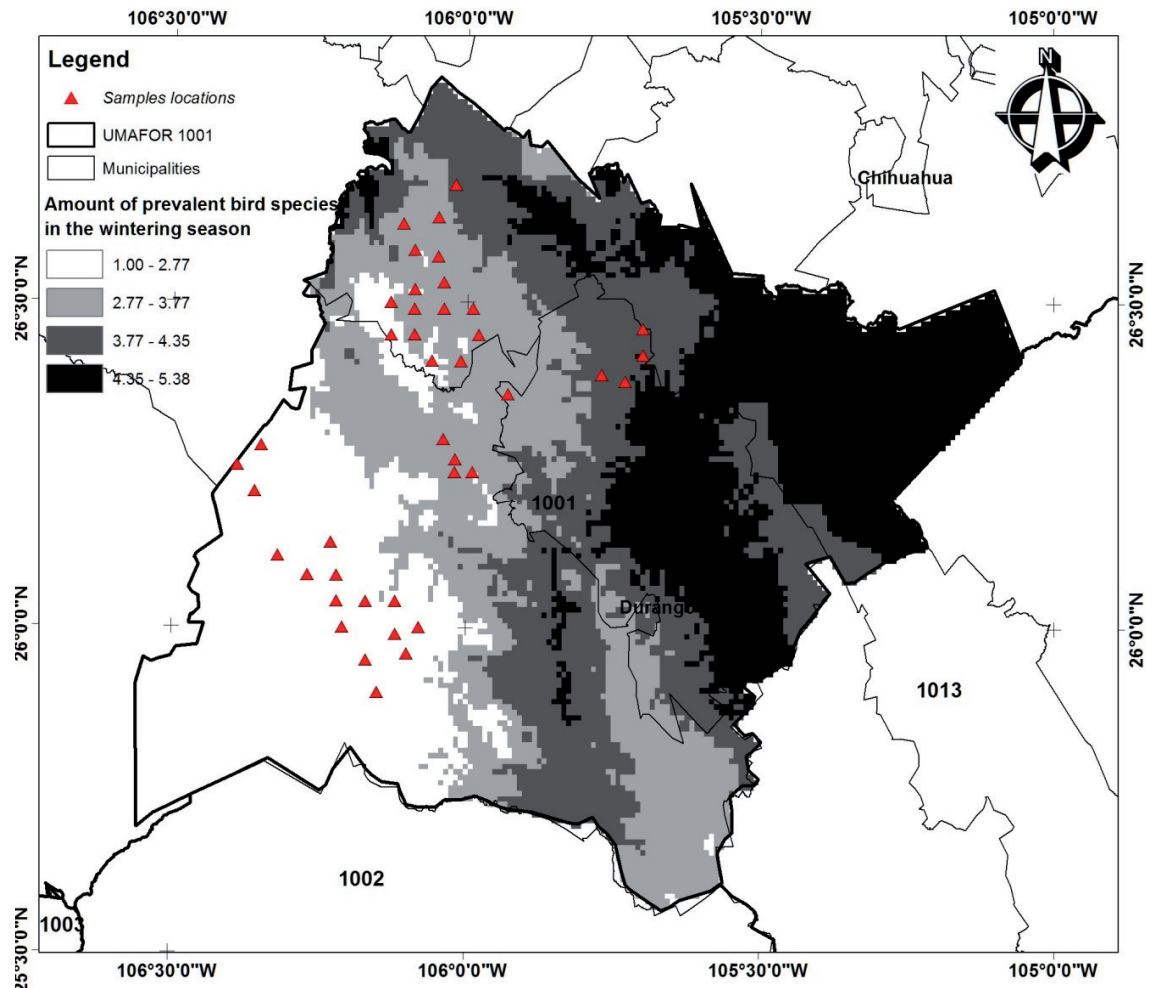

Figure 4. Model of the distribution of number of prevalent bird species $\left(\mathrm{v}_{\infty, \mathrm{BWS}}\right)$ in the wintering season 2015-2016 in the study area (Adjusted R-squared $=0.38 ;$ Residual standard error $=0.90)$ using the regression results from Table 4 .

The mean annual precipitation (MAP) from PCA factor (F) 1 , height of dead trees within the $10 \%$ of the biggest trees $\left(\mathrm{H}_{10 \%, \text { dead }}\right)$ from $\mathrm{F} 2$, tree basal area $\left(\mathrm{G}_{\text {total }}\right)$ from $\mathrm{F} 3$, and number of prevalent tree species $\left(v_{\infty, T}\right)$ from $\mathrm{F} 4$ were preselected for the regression analysis. Table 3 shows the models of bird species diversities $v_{0, B W S}, v_{2, B W S}, v_{\infty, B W S}$ in relation to the mean annual precipitation (MAP). MAP was the sole informative predictor after stepwise linear regression. The $v_{\infty, B W S}$ model performed best, with $R_{A d j}^{2}=0.38$. The total number of bird species decreased by 2.14 species on average when the MAP increased by $100 \mathrm{~mm}$ (Fig. 4).

\section{Discussion}

Sampling in this study was restricted to a single breeding and a single wintering period and is thus not representative of anything beyond these periods. Broad claims about bird diversity and the underlying factors in the study site in general are therefore not possible.

According to the results, however, there was a large difference between the individual numbers of birds observed in the study area in the breeding and the wintering season. This was mainly caused by the larger number of resident birds and migratory birds observed in the wintering season (Table A1). The larger number of sedentary birds observed in the wintering season was probably due to the numbers of young produced in 2015.

The diversity of avian species in the breeding season was not affected by the climate or forest stand variables studied. However, the bird species diversity in the wintering season was significantly weakly to moderately associated with climate variables, tree species diversity and stand density. The bird species diversity was higher at lower elevations and in drier and warmer locations of the Sierra Madre Occidental (Fig. 4), as concluded by Nocedal (1994). This author found that the coastal lowlands of the Sierra Madre Occidental are wintering grounds for long-distance bird migrants and also for short-distance or local migrants.

The numbers of prevalent bird species in the wintering season $\left(v_{\infty, B S W}\right)$, which only considers the most frequent species in a location (Gregorius 1978), was more strongly affected by the predictors studied than the other avian species richness indicators and the effective bird species diversity. Hence, the proportion of the most frequent bird species increased significantly at lower temperature, higher precipitation, higher forest side quality and stand density. Almost all of the predominant bird species were sedentary birds. The association detected is therefore mainly a local migratory phenomenon (Nocedal 1994).

These findings are in contrast to the conclusions reached in many other studies (e.g., Rahbek 1997, Rahbek and Graves 2001, Bailey et al. 2004), which have reported a positive relationship between bird species diversity and habitat heterogeneity and precipitation. However, some studies reported that avian species diversity was inversely related to woody plant species diversity as well as vertical stratification, canopy density and tree density in natural forests (Daniels et al. 1992).

Precipitation and temperature were probably the key factors influencing bird species diversity as well as tree species diversity and stand density (Fig. 2, 3 and Tables A2 and 2). Silva-Flores et al. (2014) reported that tree species diversity and tree density were weakly to moderately negatively associated with aridity, temperature and elevation range from 1,600 to 3,200 $\mathrm{m}$ in the Sierra Madre Occidental, Durango, 
Mexico. Mean annual precipitation in the growing season was slightly more significant than the winter precipitation, which should affect avian species diversity more directly in the winter (Fig. 2).

\section{Conclusions}

This investigation is an important contribution to our understanding of relationships among bird community structure and forest as well as climatic variables. We conclude that the climate model may be inaccurate or that the mean annual precipitation or the growing season precipitation may also indirectly affect bird species diversity via effects on forest vegetation. If the latter is true, several bird species would migrate to lower land in the winter because of the more suitable weather conditions (warmer and snow-free), because this forest vegetation is more attractive at this time and probably also because of the lower predation risk (Roth et al. 2006) and better energy balance (Brown and Sherry 2008). The open temperate to warm semi-dry forests and woodlands in the Sierra Madre Occidental are typically characterized by higher frequencies of Pinus cembroides, Juniperus spp. Quercus spp., shrubs, herbs and grass (González-Elizondo et al. 2013). In particular, Pinus cembroides, Juniperus spp. and Quercus spp. produce nutritious seeds and acorns for several bird species (Hubbard and McPherson 1997). The vegetative growth period is also longer and greater numbers of invertebrates (an important component of birds' diets) are therefore active at this time.

Finally, Phainopepla nitens and Spizella passerine were observed in the wintering season, although these have only been recorded as breeding birds in the region (CONABIO 2016a). Likewise, Empidonax hammondii and Accipiter striatus were detected in the breeding season, although listed only as migratory birds in the area (CONABIO 2016a).

Acknowledgements. We are grateful to the Secretaría de Recursos Naturales y Medio Ambiente de Durango, CONAFOR, Asociación de Silvicultores y Productores del Norte de Durango A.C. (Engineer J. M. Brito Chávez), J. Hernández-Velasco, S. L. Simental-Rodríguez and S. I. Arroyo Arroyo for helpful assistance. The experiments comply with the current laws of the country in which they were performed.

\section{References}

Amador, E., R. Mendoza-Salgado and J.A. De Anda-Montañez. 2006. Estructura de la avifauna durante el periodo invierno-primavera en el Estero Rancho Bueno, Baja California Sur, México. Rev. Mex. Biodivers. 77: 251-259.

Ambuel, B. and S.A. Temple. 1983. Area-dependent changes in the bird communities and vegetation of southern Wisconsin forests. Ecology 64: 1057-1068.

Bailey, S.A., M.C. Horner-Devine, G. Luck, L.A. Moore, K.M. Carney, S. Anderson, C. Betrus and E. Fleishman. 2004. Primary productivity and species richness: relationships among functional guilds, residency groups and vagility classes at multiple spatial scales. Ecography 27: 207-217.
Balda, P.R. 1969. Foliage use by birds of the Oak-Juniper woodlan and Ponderosa pine forest in Southeastern, Arizona. The Condor 71: $399-412$.

Bergner, A., M. Avci, H. Eryigit, N. Jansson, M. Niklasson, L. Westerberg and P. Milberg. 2015. Influences of forest type and habitat structure on bird assemblagesof oak (Quercus spp.) and pine (Pinus spp.) stands in southwestern Turkey. Forest Ecol. Manag. 336: 137-147.

Berlanga, H., J.A. Kennedy, T.D. Rich, M.C. Arizmendi, C.J. Beardmore, P.J. Blancher, G.S. Butcher, A.R. Couturier, A.A. Dayer, D.W. Demarest, W.E. Easton, M. Gustafson, E. IñigoElias, E.A. Krebs, A.O. Panjabi, V. Rodriguez Contreras, K.V. Rosenberg, J.M. Ruth, E. Santana Castellón, R. Ma Vidal and T. Will. 2010. Conservando a nuestras aves compartidas: la visión trinacional de Compañeros en Vuelo para la conservación de las aves terrestres. Cornell Laboratory of Ornithology, Ithaca.

Bibby, J., N.D. Burgess, D.A. Hill and S.H. Mustoe. 2000. Bird Census Techniques. Second Edition. Academic Press, London, UK.

Bitterlich, W. 1952. Die Winkelzählprobe. Ein optisches Meßverfahren zur raschen Aufnahme besonders gearteter Probeflächen für die Bestimmung der Kreisflächen pro Hektar an stehenden Waldbeständen. Forstwissenschaftliches Zentralblatt 71: 215-225.

Brown, R. and T.W. Sherry. 2008. Alternative strategies of space use and response to resource change in a wintering migrant songbird. Behav. Ecol. 19: 1315-1325.

Carey, C. 2009. The impacts of climate change on the annual cycles of birds. Phil. Trans. R. Soc. B. 364: 3321-3330.

Consejo Nacional para la Biodiversidad (CONABIO). 2016a. Red de conocimientos sobre las aves de México. http://avesmx.conabio. gob.mx. Accessed Mar. 26, 2016.

Consejo Nacional para la Biodiversidad (CONABIO). 2016b. Red de conocimientos sobre las aves de México. http://bdi.conabio.gob. $\mathrm{mx} /$ fotoweb/Grid.fwx? columns $=4 \&$ rows $=8 \&$ search $=$ Apheloco ma\%20wollweberi. Accessed March 26, 2016.

Currie, D.J., G.G. Mittelbach, H.V. Cornell, R. Field, J.F. Guégan, B.A. Hawkins, D.M. Kaufman, J.T. Kerr, T. Oberdorff, E. O'Brien and J.R.G. Turner. 2004. Predictions and tests of climate-based hypotheses of broad-scale variation in taxonomic richness. Ecol. Lett. 7: 1121-1134.

Daniels, R.J.R., N.V. Joshi and M. Gadgil. 1992. On the relationship between bird and woody plant species diversity in the Uttara Kannada district of south India. PNAS USA. 89: 5311-5315.

Development Core Team (2015) R: A language and environment for statistical computing. R Foundation for Statistical Computing, Vienna, Austria. Available: URL http://www.R-project.org/

DeWalt, S. J., S.K. Maliakal and J.S. Denslow. 2003. Changes in vegetation structure and composition along a tropical forest chronosequence: implications for wildlife. Forest Ecology and Management. 182: 139-151.

Dolby, A.S. and T.C. Grubb. 2000. Social context affects risk taking by a satellite species in a mixed-species foraging group. Behav. Ecol. 11: 110-114.

Faaborg, J., R.T. Holmes, A.D. Anders, K.L. Bildstein, K.M. Dugger, S.A.Jr. Gauthreaux, P. Heglund, K.A. Hobson, A.E. Jahn, D.H. Johnson, S.C. Latta, D.J. Levey, P.P. Marra, C.L. Merkord, E. Nol, S.I. Rothstein, T.W. Sherry, T.S. Sillett, F.R. III Thompson and N. Warnock. 2010. Conserving migratory land birds in the New World: Do we know enough? Ecol. Appl. 20: 398-418.

Gibbs, J.P., M.L. Hunter Jr and S.M. Melvin. 1993. Snag availability and communities of cavity nesting birds in tropical versus temperate forests. Biotropica 25: 236-241. 
González-Elizondo, M.S., M. González-Elizondo, L. Ruacho González, I.L. Lopez Enríquez, F.I. Retana Rentería and J.A. Tena Flores. 2013. Ecosystems and diversity of the Sierra Madre Occidental. USDA Forest Service Proceedings RMRS-P-67: 204-211.

Gregorius, H.R. 1978. The concept of genetic diversity and its formal relationship to heterozygosity and genetic distance. Math. Biosci. 41: 253-432.Hubbard, J.A. and G.R. McPherson. 1997. Acorn selection by Mexican jays: a test of a tri-trophic symbiotic relationship hypothesis. Oecologia 110: 143-146.

Hubbard, J. A. and G. R. McPherson. 1997. Acorn selection by Mexican jays: a test of a tri-trophic symbiotic relationship hypothesis. Oecologia 110: 143-146.

Hutchinson, M.E. 2004. Anusplin Version 4.3. The Australian National University. - Centre for Resource and Environmental Studies. Canberra

Hutto, R.L. 1989. The effects of habitat alteration on migratory land birds in a west Mexican tropical deciduous forest: a conservation perspective. Conserv. Biol. 3: 138-148.

Kirby, J.S., A.J. Stattersfield, S.H.M. Butchart, M.I. Evans, R.F Grimmett, V.R. Jones, J. O'Sullivan, G.M. Tucker and I. Newton. 2008. Key conservation issues for migratory land and waterbird species on the world's major flyways. Bird Conserv. Internat. 18: S49-S73.

Kruskal, W.H. and W.A. Wallis. 1952. Use of Ranks in One-Criterion Variance Analysis. J. Am. Stat. Assoc. 47: 583-621.

Lopes, R.H., I.D. Reid and P.R. Hobson. 2007. The two-dimensional Kolmogorov-Smirnov test. XI International Workshop on Advanced Computing and Analysis Techniques in Physics Research, Amsterdam, the Netherlands. pp. 1-12.

Martínez-Guerrero, J.H., C. Wehenkel, M.E. Pereda-Solís, A. Panjabi, G. Levandoski, J. Corral-Rivas and R. Díaz-Moreno. 2011. Relationship between Ammodramus bairdii, Audubuon, 1844 , soil cover and attributes of winter vegetation in Northwestern Mexico. Agrociencia 45: 443-451.

Massey, B.W. and E. Palacios. 1994. Avifauna of the wetlands of Baja California Mexico: current status. In: J.R. Jehl Jr., and N.K. Johnson (eds.), A Century of Avifaunal Change in Western North America. Studies in Avian Biology 15: 45-57.

McNab, W.H. 1989. Terrain shape index: quantifying effect of minor landforms on tree height. Forest Sci. 35: 91-104.

Mellink, E., E. Palacios and S. González. 1996. Notes on nesting birds of the Ciénega de Santa Clara saltflat, Northwester Sonora, México. Western Birds 27:202-203.

NaturaLista. 2016a. http://conabio.inaturalist.org/taxa/145

245-Setophaga-coronata Chipe coronado (Setophaga coronata). Accessed March 26, 2016.

NaturaLista. 2016b. http://naturalista.conabio.gob.mx/taxa/145308 Spinus-psaltria Jilguero dominico (Spinus psaltria). Accessed March 26, 2016.

Nocedal, J. 1994. Local migrations of insectivorous birds in western Mexico: implications for the protection and conservation of their habitats. Bird Conserv. Internat. 4: 129-142.

Perez-Moreno, H., E. Martínez-Meyer, J. Soberón-Maneiro and O. Rojas Soto. 2016. Climatic patterns in the establishment of wintering areas by North American migratory birds. Ecol. Evol. 6: 2022-2033.

Pohlert, T. 2014. The Pairwise Multiple Comparison of Mean Ranks Package (PMCMR)[Internet]. R package. [cited 2015 Feb 05] Available from: http://cran.r-project.org./web/ packages/ PMCMR/vignettes/PMCMR.pdf
Rahbek, C. 1997. The relationship among area, elevation, and regional species richness in neotropical birds. Am. Nat. 149: 875-902.

Rahbek, C. and G.R. Graves. 2001. Multiscale assessment of patterns of avian species richness. PNAS 98: 4534-4539.

Rahbek, C., N.J. Gotelli, R.K. Colwell, G.L Entsminger, T.F.L. Rangel and G.R. Graves. 2007. Predicting continental-scale patterns of bird species richness with spatially explicit models. Proc. R. Soc. B. 274: 165-74.

Ralph, C.J. 1985. Habitat association patterns of forest and steppe birds of Northern Patagonia, Argentina. The Condor 87: 471483.

R Development Core Team. 2015. R: A language and environment for statistical computing. R Foundation for Statistical Computing, Vienna, Austria. URL http://www.R-project.org/.

Rehfeldt, G.E. 2006. A spline model of climate for the Western United States. Gen. Tech. Rep. RMRS-GTR-165. U.S. Department of Agriculture, Forest Service, Rocky Mountain Research Station, Fort Collins, Colorado, USA.

Reineke, L.H. 1933. Perfecting a stand-density index for even-aged forests. J. Agric. Res. 46: 627-638.

Roth II, T.C., S.L. Lima and W.E. Vetter. 2006. Determinants of predation risk in small wintering birds: the hawk's perspective. Behav. Ecol. Sociobiol. 60: 195-204.

Silva-Flores, R., G. Perez-Verdin and C. Wehenkel. 2014 Relationship between diversity of tree species and climatic factors in the Sierra Madre Occidental, Mexico. PloS One 9(8):e105034. DOI: 10.1371/journal.pone.0105034.

Somveille, M., A.S.L Rodrigues and A. Manica. 2015. Why do birds migrate? A macroecological perspective. Global Ecol. Biogeogr. 24: 664-674

Somveille, M., A. Manica, S.H.M. Butchart and A.S.L. Rodrigues 2013. Mapping global diversity patterns for migratory birds. PLOS ONE 8, e70907.

Terborgh, J., S.K. Robinson, T.A. Parker, C.A. Munn and N. Pierpont. 1990. Structure and organization of an Amazonian forest bird community. Ecol. Monogr. 60: 213-238.

Venables, W.N. and B.D. Ripley. 2002. Modern Applied Statistics with $S$. Fourth Edition. Springer, New York.

Wolfgang, K.H. and S. Leopold. 2012. Applied Multivariate Statistical Analysis. Springer Heidelberg Dordrecht London, New York.

XLSTAT 2016. XLSTAT Software. Version 2015.6.01.25740. Copyright Addinsoft 1995-2016. Available: URL https//www. xlstat.com

Zellweger, F., A. Baltensweiler, C. Ginzler, T. Roth, V. Braunisch, H Bugmann and K. Bollmann. 2016. Environmental predictors of species richness in forest landscapes: abiotic factors versus vegetation structure. J. Biogeogr. 2016 1-11. doi:10.1111/jbi.12696.

Received November 2, 2016 Revised February 23, 2017 Accepted April 27, 2017

\section{Electronic appendix}

Table A1. List of birds watched in different seasons.

Table A2. Descriptive statistics for the variables studied: minimum, maximum, mean and standard deviation for 41 observations per variable.

The file may be downloaded from www.akademiai.com. 